\title{
ANALISIS INTERVENSI TEKNIK DISTRAKSI MENONTON KARTUN EDUKASI TERHADAP SKALA NYERI PADA ANAK USIA TODDLER SAAT PENGAMBILAN DARAH INTRAVENA DI RUANG CEMPAKA ANAK RUMAH SAKIT PELNI JAKARTA
}

\author{
I Made Mertajaya ${ }^{1}$ \\ ${ }^{1}$ Staff Pengajar Prodi D-III Keperawatan Fakultas Vokasi UKI Jakarta \\ E-mail : immerta@yahoo.com
}

\begin{abstract}
ABSTRAK
Nyeri adalah fenomena multidimensional sehingga sulit untuk didefinisikan, pengalaman personal dan subjektif, dan tidak ada dua individu yang merasakan nyeri dalam pola yang sama, dalam beberapa kasus perawatan pada anak-anak management rasa sakit ini salah satunya adalah dengan teknik distraksi, teknik distraksi merupakan salah satu upaya untuk mengurangi nyeri, dalam perawatan anak-anak teknik ini patut dikuasai oleh para tenaga kesehatan khususnya perawat. Penelitian ini bertujuan untuk menggambarkan atau mengetahui intervensi teknik distraksi menonton kartun edukasi untuk menurunkan skala nyeri pada anak usia toddler pada saat pengambilan darah intravena. Dari beberapa penelitian didapat bahwa faktor-faktor yang memengaruhi nyeri yaitu usia, pengetahuan, jenis kelamin, pengalaman nyeri sebelumnya, temperamen, faktor budaya dan keluarga, faktor situasional, arti nyeri, persepsi nyeri, toleransi nyeri, reaksi nyeri, ansietas, harapan dan efek placebo.

Metode penelitian ini merupakan deskriptif sederhana dengan desain penelitian adalah studi kasus, subjek penelitian yang diteliti sebanyak 2 orang.

Variabel independent dalam penelitian ini yaitu teknik distraksi menonton kartun edukasi sedangkan variabel dependent meliputi skala nyeri. Analisis hubungan antara variabel independent dengan variabel dependent dengan menggunakan studi kasus. Hasil penelitian studi kasus yang telah dilakukan menunjukkan bahwa terjadinya penurunan skala nyeri pada anak usia toddler saat pengambilan darah intravena setelah diberikan intervensi teknik distraksi menonton kartun edukasi, anak yang lebih muda memiliki tingkat nyeri yang lebih tinggi dan semakin bertambah usia tingkat nyerinya menjadi lebih rendah.

Saran yang diajukan adalah agar teknik distraksi menonton kartun edukasi sangat perlu menjadi rujukan asuhan keperawatan khususnya anak serta dilaksanakan secara sungguh-sungguh dalam hal menurunkan skala nyeri saat pengambilan darah intravena pada anak.
\end{abstract}

Kata Kunci : Skala nyeri, Teknik distraksi, Usia toddler.

\section{PENDAHULUAN}

Anak yang menjalani perawatan di Rumah Sakit pada dasarnya memberikan respon penerimaan yang buruk ketika dilakukan tindakan penusukan pada intravena, diantaranya anak menjadi lebih agresif dan tidak kooperatif dengan petugas kesehatan. Kondisi ini mempersulit perawat dalam melaksanakan tindakan keperawatan (Supartini, 2004). Carter dan Simons pada tahun 2014 
melakukan penelitian pada anak-anak $(\mathrm{n}=$ 3822) yang dirawat di delapan Rumah Sakit Anak di Canada dan menemukan bahwa dalam 24 jam saat penelitian, terdapat 18,929 prosedur yang dicatat, dan $87 \%$ dari anak mengalami satu atau lebih prosedur yang menimbulkan nyeri. Penelitian yang dilakukan oleh Utami tahun 2014 menyatakan bahwa terdapat beberapa faktor yang dapat menimbulkan stress ketika anak menjalani hospitalisasi seperti lingkungan rumah sakit, berpisah dengan orang-orang yang berarti, kehilangan kendali, cedera tubuh dan nyeri.

Nyeri merupakan suatu perasaan atau pengalaman yang tidak nyaman baik secara sensori maupun emosional yang dapat ditandai dengan kerusakan jaringan ataupun tidak (Association for the study of pain). Tipe dari nyeri adalah : Cutaneous pain, Viseral pain, Neuropathic pain, Acute pain dan chronic pain. Asosiasi Nyeri Internasional tahun 1997 menggambarkan nyeri sebagai perasaan yang tidak menyenangkan dan pengalaman emosional yang dihubungkan dengan aktual atau potensial kerusakan jaringan tubuh. Selanjutnya Perry dan Potter tahun 2005 menyatakan bahwa nyeri seringkali merupakan tanda yang menyatakan ada sesuatu yang secara fisiologis terganggu yang menyebabkan seseorang meminta pertolongan. Hasil penelitian dari Odhner (2003) mengembangkan NVPS berbasis pada satu alat ukur nyeri FLACC (faces, legs, activity, cry, consolability) digunakan untuk menilai nyeri pada pasien luka bakar, alat ukur NVPS berdasarkan pada lima domain pokok yaitu : ekspresi wajah, aktivitas/gerakan, penjagaan/posisi tubuh, tanda fisiologis I (tekanan darah sistolik, nadi, dan laju pernapasan) dan tanda fisiologis II (kulit, respon pupil, keringat) setiap domain mencetak skala nol paling rendah sampai dengan skala dua paling tinggi.

Anak-anak sangat rentan terhadap penyakit dan hospitalisasi (Wong, 2008). Hospitalisasi merupakan suatu proses yang karena suatu alasan yang berencana atau darurat, mengharuskan anak untuk tinggal dirumah sakit, menjalani terapi dan perawatan sampai pemulangannya kembali kerumah (Supartini, 2004). Anak memiliki ketahanan fisik yang lebih rentan, dibandingkan orang dewasa yang memiliki ketahanan fisik lebih baik (Aziz, 2005).

Manajemen nyeri atau tindakan untuk mengatasi nyeri yang biasa dilakukan perawat ruangan pada anak yaitu teknik nafas dalam dan mengalihkan anak dengan bercerita, namun tidak semua perawat menerapkan teknik tersebut. Teknik distraksi berupa menonton kartun animasi juga jarang dilakukan untuk mengurangi nyeri saat pengambilan darah intravena pada anak. Padahal, manajemen nyeri sangat penting dilakukan oleh seorang perawat terutama pada anak-anak (Sarfika, Yanti, \& Winda, 2015).

Distraksi adalah metode atau teknik yang dapat digunakan untuk mengurangi nyeri dengan mengalihkan perhatian klien dari nyeri (Asmadi, 2008). Terdapat beberapa macam jenis distraksi diantaranya distraksi penglihatan, distraksi pendengaran, distraksi sentuhan, distraksi pernafasan, distraksi imajinasi terbimbing distraksi intelektual (Tamsuri, 2007). Kombinasi antara distraksi pendengaran (audio) dan distraksi penglihatan (visual) disebut distraksi audiovisual, yang digunakan untuk mengalihkan perhatian pasien terhadap hal-hal yang membuatnya 
tidak nyaman, cemas atau takut dengan cara menampilkan tayangan favorit berupa gambar-gambar bergerak dan bersuara ataupun animasi dengan harapan pasien asik terhadap tontonannya sehingga mengabaikan rasa tidak nyaman dan menunjukkan respons penerimaan yang baik (Tamsuri, 2007).

Salah satu teknik distraksi yang dapat dilakukan pada anak dalam penatalaksanaan nyeri adalah menonton kartun animasi (Wong, 2009). Ketika anak lebih fokus pada kegiatan menonton film kartun, hal tersebut membuat impuls nyeri akibat adanya cedera tidak mengalir melalui tulang belakang, pesan tidak mencapai otak sehingga anak tidak merasakan nyeri (Brannon dkk, 2013).

Dari uraian diatas dan melihat fenomena yang terjadi dilapangan, peneliti tertarik untuk melakukan penelitian tentang "Analisis Intervensi Teknik Distraksi Menonton Kartun Edukasi Terhadap Nyeri Pada Anak Usia Toddler Saat Pengambilan Darah Intravena di Ruang Cempaka Anak Rumah Sakit PELNI Jakarta".

\section{METODE PENELITIAN}

Penelitian ini menggunakan desain penelitian deskriptif dengan pendekatan studi kasus. Penelitian dengan metode studi kasus merupakan rancangan penelitian yang mencakup pengkajian satu unit penelitian secara intensif, misal satu pasien, keluarga, kelompok, komunitas, atau institusi.

Penelitian studi kasus ini melibatkan 2 (dua) individu yaitu An. H dan An. M.Z yang dilakukan teknik distraksi menonton kartun edukasi saat dilakukan pengambilan darah intravena dan 2 anak tersebut diberikan teknik distraksi menonton kartun edukasi saat dilakukan pengambilan darah intravena lalu di nilai skala nyerinya. Teknik distraksi menonton kartun edukasi diberikan pada anak dengan menggunakan video kartun edukasi yang menarik perhatian dan disukai anak, menggunakan media smartphone.

Penentuan subjek penelitian ditetentukan terlebih dahulu dengan kriteria inklusi dan eksklusi, Kriteria inklusi pada subjek penelitian ini adalah anak usia (1-3 tahun), anak dilakukan pengambilan darah tidak lebih dari 2 kali, orang tua atau keluarga bersedia apabila anak menjadi subjek penelitian penelitian dan mampu berkomunikasi secara verbal dan non verbal dan kriteria eksklusi pada subjek penelitian ini adalah anak mengalami gangguan kesadaran, anak mendapat obat analgetik, pengambilan darah disertai pemasangan infus, anak yang mengalami nyeri hebat dari penyakit yang diderita, orang tua atau keluarga tidak kooperatif.

Fokus studi dari penelitian ini adalah "penurunan skala nyeri pada anak usia toddler saat pengambilan darah intravena yang mendapat tindakan teknik distraksi menonton kartun edukasi“. Instrumen penelitian yang digunakan dalam penelitian ini adalah lembar observasi klien, lembar inform concent, lembar penilaian nyeri FLACC (Face, Legs, Activity, Cry, and Consolability) yang telah teruji validitas dan reliabilitasnya, smartphone yang berisi video kartun edukasi, serta smartphone untuk merekam ekspresi subjek penelitian dan tindakan yang dilakukan. Kegiatan pengumpulan data sudah memenuhi prosedur teknis dan administrasi.

Kegiatan dilakukan di Ruang Cempaka Anak Rumah Sakit Pelni Jakarta, 
pemilihan lokasi ini didasarkan kepada pertimbangan kemudahan baik dari sisi teknis dan administratif, kegiatan pengamatan dilakukan selama kurun waktu 3 hari, dan telah menjalankan etika penelitian yang berlaku.

\section{HASIL DAN PEMBAHASAN PENELITIAN.}

Penelitian studi kasus ini dilakukan mulai tanggal 10 sampai dengan 12 Juli 2017 pada dua orang Subjek atas nama An. $\mathrm{H}$ yang berusia 1 tahun sebagai Subjek I dan An. M.Z yang berusia 2 tahun sebagai Subjek II. Hasil dan pembahasan dari kegiatan penelitian ini dipaparkan dalam paparan dan bahasan seperti berikut ini.

\section{A. Hasil Penelitian.}

\section{Gambaran Umum Lingkungan studi Kasus.}

Penelitian studi kasus ini dilakukan di Rumah Sakit PELNI Jakarta yang beralamat di Jln. Aipda KS. Tubun 92-94 Jakarta.

Rumah sakit ini memiliki beberapa fasilitas, seperti IGD, poli umum dan spesialis, ICU, HCU, Kamar Bedah, Ruang Khusus HD, Ruang Perawatan Dewasa dan Anak Rawat Inap mulai dari kelas III sampai dengan VVIP, tempat rehabilitasi, sarana olahraga, dan lain-lain. Ruang Cempaka Anak merupakan salah satu ruangan rawat inap khusus anak dari beberapa ruangan rawat inap yang ada di Rumah Sakit PELNI Jakarta.

Subjek I bernama An. H, berjenis kelamin laki-laki, berusia 1 tahun, dengan No. RM adalah 6192 00, keluarga yang mendampingi saat penelitian yaitu ayah, pengalaman pengambilan darah sebanyak 1 kali, diagnosa medisnya adalah diare, tempat pengambilan darah pada vena cephalica, serta lama pengambilan darahnya adalah 1 menit 30 detik.

Subjek I merupakan anak tunggal. Saat ini Subjek I menjalani rawat inap di ruang Cempaka Anak, berambut pendek, kulit sawo matang, dan tidak memiliki cacat fisik. Berdasarkan pengamatan, Subjek I tampak diam, rileks, ingin bermain dan tenang saat bersama ayahnya. Subjek I cenderung lebih dekat dengan ibunya.

Subjek II bernama An. M.Z, berjenis kelamin laki-laki, berusia 2 tahun, dengan No. RM adalah 6087 73, keluarga yang mendampingi saat penelitian yaitu ibu, pengalaman pengambilan darah sebanyak 1 kali, diagnosa medisnya adalah diare, tempat pengambilan darah pada vena basilica, serta lama pengambilan darahnya adalah 40 detik.

Subjek II merupakan anak ke-2 dari dua bersaudara. Saat ini Subjek II menjalani rawat inap di ruang Cempaka Anak, berambut pendek, kulit sawo matang, dan tidak memiliki cacat fisik. Berdasarkan pengamatan, Subjek II tampak tidak ada ekspresi atau senyuman tertentu, posisi rileks, tidak menangis, ingin bermain dan tenang saat bersama ibunya. Subjek II cenderung lebih dekat dengan ibunya.

\section{Fokus Studi.}

Fokus Studi dari kegiatan peneltian Studi kasus ini adalah memaparkan tentang Upaya Penurunan Skala Nyeri Pada Anak Usia Toddler khususnya Saat Pengambilan Darah Intravena yang dalam kegiatan ini mencoba untuk meneliti/ melakukan pengamatan yang difokuskan pada saat pengambilan darah Intervensi 
melalui Teknik Distraksi Menonton Kartun Edukasi yang di putar pada saat pengambilan darah dilakukan.

\section{Kondisi Subjek sebelum dan sesudah diberikan intervensi}

Kondisi Subjek Penelitian sebelum diberikan intervensi dipaparkan dalam paparan berikut ini.

\section{Subjek I}

Setelah dilakukan pengamatan dan wawancara pada ayah subjek yang mendampingi didapatkan hasil yang menunjukkan bahwa Subjek I tampak diam, rileks, ingin bermain dan tenang saat bersama ayahnya, Subjek I cukup kooperatif pada penelitian yang akan dilakukan, sudah pernah dirawat sebelumnya di Rumah Sakit PELNI sekitar 7 bulan yang lalu di ruang Cempaka Anak.

\section{Subjek II}

Setelah dilakukan pengamatan dan wawancara pada ibu subjek yang mendampingi didapatkan hasil yang menunjukkan bahwa Subjek II tampak tidak ada ekspresi atau senyuman tertentu, posisi rileks, tidak menangis, ingin bermain dan tenang saat bersama ibunya, Subjek II sangat kooperatif pada penelitian yang akan dilakukan, sudah pernah dirawat sebelumnya di Rumah Sakit PELNI sekitar 5 bulan yang lalu dengan diagnosa medis demam typoid.

\section{Proses Intervensi kegiatan.}

Proses Intevensi yang dilakukan terhadap subjek I dan Subjek II dipaparkan dalam paparan seperti berikut ini.

\section{Subjek I.}

Pertemuan - 1 dilakukan pada hari Rabu, 12 Juli 2017, Pukul 09.40 WIB pertemuan ini dilakukan bertujuan untuk Menggambarkan intervensi teknik distraksi menonton kartun edukasi untuk menurunkan skala nyeri pada Subjek I saat pengambilan darah intravena, respon yang diperoleh terlihat bahwa konsentrasi Subjek I teralihkan dari tingkat nyeri berat menjadi sedang. Penilaian skala nyeri dilakukan sebanyak empat kali yaitu pada 3 menit sebelum dilakukan pengambilan darah intravena yaitu 0 (tidak ada nyeri) ditunjukkan dengan tidak ada ekspresi, posisi rileks, berbaring tenang, tidak menangis, ingin bermain. Saat dilakukan pengambilan darah intravena mengalami nyeri berat (skala nyeri 9) ditandai dengan menyeringai lebih sering, tangan ngepal, tungkai naik ke atas, tegang, menangis keras, rewel, tidak ada kontak mata. Pada menit ke-3 setelah dilakukan pengambilan darah intravena masih mengalami nyeri berat tetapi skala nyerinya sudah menurun (skala nyeri 7) ditandai dengan tidak berminat, menyeringai kadang-kadang, gelisah, tegang, bergerak ke depan dan ke belakang, menangis keras, rewel, mengerang, tidak ada kontak mata. Serta pada menit ke-5 setelah dilakukan pengambilan darah intravena mengalami nyeri sedang (skala nyeri 4) yang ditandai dengan menarik diri, tidak berminat, posisi rileks, tegang, merengek, minta peluk, rewel.

Kemajuan yang terjadi adalah Terjadinya penurunan skala nyeri dari 3 menit sebelum pengambilan darah intravena menunjukkan tidak ada nyeri, saat dilakukan pengambilan darah intravena mengalami skala nyeri berat yaitu dengan skala 9. Pada menit ke-3 
setelah pengambilan darah intravena skala nyeri menurun menjadi 7 yaitu masih pada skala nyeri berat. Pada menit ke- 5 setelah pengambilan darah intravena mengalami penurunan kembali yaitu pada skala nyeri 4 (nyeri sedang).

\section{Subjek II}

Pertemuan - 1 dilakukan pada hari Rabu, 12 Juli 2017, Pukul 09.55 WIB tujuan pertemuan ini adalah Menggambarkan intervensi teknik distraksi menonton kartun edukasi untuk menurunkan skala nyeri pada Subjek II saat pengambilan darah intravena.

Respon yang diperoleh menunjukkan bahwa Konsentrasi Subjek II teralihkan dari tingkat nyeri sedang menjadi tidak ada nyeri. Penilaian skala nyeri dilakukan sebanyak empat kali yaitu pada 3 menit sebelum dilakukan pengambilan darah intravena yaitu 0 (tidak ada nyeri) ditunjukkan dengan tidak ada ekspresi, posisi rileks, berbaring tenang, tidak menangis, ingin bermain. Saat dilakukan pengambilan darah intravena mengalami nyeri sedang (skala nyeri 6) ditandai dengan menyeringai lebih sering, tidak tenang, gelisah, tegang, menggeliat, merengek, terkadang mengeluh. Pada menit ke-3 setelah dilakukan pengambilan darah intravena skala nyeri menurun drastis yaitu 0 (tidak ada nyeri) ditunjukkan dengan tidak ada ekspresi, posisi rileks, berbaring tenang, tidak menangis, ingin bermain. Pada menit ke-5 setelah dilakukan pengambilan darah intravena yaitu tidak ada nyeri (skala nyeri 0) ditunjukkan dengan tidak ada ekspresi, posisi rileks, berbaring tenang, tidak menangis, ingin bermain.

Kemajuan yang terjadi adalah Terjadinya penurunan skala nyeri dari 3 menit sebelum pengambilan darah intravena menunjukkan tidak ada nyeri, saat pengambilan darah intravena mengalami menunjukkan skala nyeri sedang yaitu dengan skala nyeri 6 , pada menit ke-3 setelah pengambilan darah intravena mengalami penurunan yang cukup signifikan dengan skala nyeri 0 (tidak ada nyeri), serta pada menit ke-5 setelah pengambilan darah intravena masih sama menunjukkan bahwa tidak ada nyeri.

\section{Kondisi Subjek Penelitian setelah Diberikan Intervensi.}

Kondisi Subjek Penelitian setelah diberikan intervensi dipaparkan dalam paparan seperti berikut ini.

\section{Subjek I}

Evaluasi : Pada menit ke-3 setelah dilakukan pengambilan darah intravena masih mengalami nyeri berat tetapi skala nyerinya sudah menurun (skala nyeri 7 ) ditandai dengan tidak berminat, menyeringai kadang-kadang, gelisah, tegang, bergerak ke depan dan ke belakang, menangis keras, rewel, mengerang, tidak ada kontak mata. Serta pada menit ke-5 setelah dilakukan pengambilan darah intravena mengalami nyeri sedang (skala nyeri 4) yang ditandai dengan menarik diri, tidak berminat, posisi rileks, tegang, merengek, minta peluk, rewel.

\section{Subjek II}

Evaluasi : Pada menit ke-3 setelah dilakukan pengambilan darah intravena skala nyeri menurun drastis yaitu 0 (tidak ada nyeri) ditunjukkan dengan tidak ada ekspresi, posisi rileks, berbaring tenang, tidak menangis, ingin bermain. Pada menit ke-5 setelah dilakukan pengambilan darah intravena yaitu tidak ada nyeri (skala nyeri 0) ditunjukkan dengan tidak ada ekspresi, 
posisi rileks, berbaring tenang, tidak menangis, ingin bermain.

\section{Perbandingan Kondisi Subjek sebelum dan sesudah dilakukan intervensi.}

Perbandingan kondisi subjek sesudah dilakukan intervensi pada subjek I dan II dapat dianalisis kembali pada paparan berikut ini.

\section{Subjek I.}

Penilaian skala nyeri yang digunakan adalah FLACC (Face, Legs, Activity, Cry, and Consolability) pada anak usia toddler (1-3 tahun). Rentang skala nyeri untuk FLACC terdiri dari skala nyeri 0 sampai 10 adalah rentang skala 0 untuk tidak ada nyeri, skala 1-3 untuk nyeri ringan, skala 4-6 untuk nyeri sedang, dan skala 7-10 untuk nyeri berat.
Pada Subjek I diperoleh data yang menunjukan data pada 3 menit sebelum pengambilan darah, data pada Saat pengambilan darah, data pada Menit ke-3 setelah pengambilan darah dan data pada Menit ke-5 setelah pengambilan darah.

Hasil pengamatan pada Subjek I menunjukan bahwa 3 menit sebelum pengambilan darah aspek wajah, tungkai, Aktivitas, tangisan dan ketenangan anak masih dalam kondisi tenang tidak menunjukan rasa nyeri, berbeda pada saat pengambilan darah, menit ke-3 setelah pengambilan darah, dan menit ke-5 setelah pengambilan darah menunjukkan ada perasaan nyeri yang dirasakan subjek I meskipun dalam skala nyeri yang ringan. Untuk lebih jelasnya dapat dianalisis pada tabel berikut ini.

Tabel 1

Perbandingan Kondisi Subjek Sebelum Sampai Sesudah Dilakukan Intervensi Pada Subjek I.

\begin{tabular}{clcccc}
\hline No. & Aspek & $\begin{array}{c}\text { 3 menit } \\
\text { sebelum } \\
\text { pengambilan } \\
\text { darah }\end{array}$ & $\begin{array}{c}\text { Saat } \\
\text { pengambilan } \\
\text { darah }\end{array}$ & $\begin{array}{c}\text { Menit ke-3 } \\
\text { setelah } \\
\text { pengambilan } \\
\text { darah }\end{array}$ & $\begin{array}{c}\text { Menit ke-5 } \\
\text { setelah } \\
\text { pengambilan } \\
\text { darah }\end{array}$ \\
\hline 1 & Face= wajah & 0 & 2 & 1 & 1 \\
2 & Legs= tungkai & 0 & 2 & 1 & 0 \\
3 & Activity=aktivitas & 0 & 1 & 1 & 1 \\
4 & Cry= tangisan & 0 & 2 & 2 & 1 \\
5 & Consolability=ketenangan & 0 & 2 & 2 & 1 \\
\hline & Jumlah Skor Nyeri & 0 & 9 & 7 & 4 \\
\hline
\end{tabular}

\section{Subjek II}

Seperti halnya pada Subjek I penilaian nyeri pada Subjek II ini pengukuran dan atau penilaian skala nyeri yang digunakan adalah FLACC (Face, Legs, Activity, Cry, and Consolability) pada anak usia toddler (1-3 tahun). Rentang skala nyeri untuk FLACC terdiri dari skala nyeri 0 sampai 10 adalah rentang skala 0 untuk tidak ada nyeri, skala 1-3 untuk nyeri ringan, skala
4-6 untuk nyeri sedang, dan skala 7-10 untuk nyeri berat.

Begitu juga dengan Aspek yang diamati pada subjek II sama dengan pengamatan pada subjek I yaitu data intervensi pada 3 menit sebelum pengambilan darah, data pada Saat pengambilan darah, data pada Menit ke-3 setelah pengambilan darah dan data pada Menit ke-5 setelah pengambilan darah. 
Hasil pengamatan pada Subjek II menunjukan bahwa 3 menit sebelum pengambilan darah aspek wajah, tungkai, Aktivitas, tangisan dan ketenangan anak masih dalam kondisi tenang tidak menunjukkan rasa nyeri, berbeda pada saat pengambilan darah Subjek II menunjukkan rasa nyeri skala ringan, namun Subjek II pada menit ke-3 setelah pengambilan darah, dan menit ke- 5 setelah pengambilan darah menunjukkan tidak ada perasaan nyeri yang dirasakan. Untuk lebih jelasnya dapat dianalisis kembali pada tabel berikut ini.

Tabel 2

Perbandingan Kondisi Subjek Sebelum Sampai Sesudah Dilakukan Intervensi Pada Subjek II

\begin{tabular}{clcccc}
\hline No. & Aspek & $\begin{array}{c}\text { 3 menit } \\
\text { sebelum } \\
\text { pengambilan } \\
\text { darah }\end{array}$ & $\begin{array}{c}\text { Saat } \\
\text { pengambilan } \\
\text { darah }\end{array}$ & $\begin{array}{c}\text { Menit ke-3 } \\
\text { setelah } \\
\text { pengambilan } \\
\text { darah }\end{array}$ & $\begin{array}{c}\text { Menit ke-5 } \\
\text { setelah } \\
\text { pengambilan } \\
\text { darah }\end{array}$ \\
\hline 1 & Face= wajah & 0 & 2 & 0 & 0 \\
2 & Legs= tungkai & 0 & 1 & 0 & 0 \\
3 & Activity= aktivitas & 0 & 1 & 0 & 0 \\
4 & Cry= tangisan & 0 & 1 & 0 & 0 \\
5 & Consolability=ketenangan & 0 & 1 & 0 & 0 \\
\hline Jumlah Skor Nyeri & 0 & 6 & 0 & 0 \\
\hline
\end{tabular}

\section{Analisis perbandingan}

Dari tabel 1 dan 2 menggambarkan kondisi Subjek I dan Subjek II pada saat intervensi dilakukan dapat digambarkan bahwa pada Subjek I lebih banyak mengalami rasa sakit skala ringan dibandingkan pada Subjek II yang hanya merasakan sakit pada saat ringan pada pengambilan darah saja setelah itu pada menit ke-3 dan menit ke-5 subjek II tidak merasakan nyeri dari intervensi yang sudah dilakukan.

\section{B. Pembahasan Hasil Penelitian}

Subjek I dan II sama-sama sudah pernah mengalami pengambilan darah intravena atau pemasangan infus sebelumnya sebanyak 1 kali. Menurut Rudolph (2006) menyatakan bahwa pengalaman anak terhadap kualitas sensorik, dampak emosional, dan strategi beradaptasi yang berhubungan dengan nyeri dipengaruhi oleh pengalaman mereka sebelumnya. Perry dan Potter (2005), juga menyatakan setiap individu belajar dari pengalaman nyeri sebelumnya, namun pengalaman nyeri sebelumnya tidak selalu berarti bahwa individu tersebut akan menerima nyeri lebih mudah pada masa yang akan datang.

Tingkat nyeri kedua Subjek saat dilakukan penelitian mengalami penurunan skala nyeri. Ball, Bindler, dan Cowen ((2010) : 524) menyatakan nyeri yang dirasakan oleh subjek penelitian saat dilakukan pengambilan darah intravena disebabkan oleh adanya penusukan jarum ke vena sehingga menyebabkan rusaknya jaringan kulit. Serat A-delta myelinated yang besar dengan cepat mengirimkan rasa sakit yang tajam dan terlokalisasi dengan baik.

Penurunan skala nyeri disebabkan karena selama proses intervensi ini kedua Subjek menunjukkan perubahan tingkat 
skala nyeri yang cukup signifikan. Subjek I menunjukkan skala nyeri pada 3 menit sebelum dilakukan pengambilan darah intravena yaitu 0 (tidak ada nyeri), saat dilakukan pengambilan darah intravena mengalami nyeri berat (skala nyeri 9), pada menit ke-3 setelah dilakukan pengambilan darah intravena masih mengalami nyeri berat tetapi skala nyerinya sudah menurun (skala nyeri 7), serta pada menit ke-5 setelah dilakukan pengambilan darah intravena mengalami nyeri sedang (skala nyeri 4).

Sedangkan penelitian pada Subjek II menunjukkan skala nyeri pada 3 menit sebelum dilakukan pengambilan darah intravena yaitu 0 (tidak ada nyeri), saat dilakukan pengambilan darah intravena mengalami nyeri sedang (skala nyeri 6), pada menit ke-3 setelah dilakukan pengambilan darah intravena skala nyeri menurun drastis yaitu 0 (tidak ada nyeri), serta pada menit ke-5 setelah dilakukan pengambilan darah intravena yaitu tidak ada nyeri (skala nyeri 0 ).

Perubahan tingkat skala nyeri yang cukup signifikan disebabkan oleh perbedaan usia kedua Subjek yaitu usia anak yang lebih muda memiliki tingkat nyeri yang lebih tinggi dan semakin bertambah usia tingkat nyerinya menjadi lebih rendah. Perry dan Potter (2005) menyatakan bahwa usia merupakan variabel penting yang mempengaruhi nyeri khususnya anak-anak.

Perbedaan perkembangan diantara kelompok usia mempengaruhi reaksi terhadap nyeri. Faktor situasional cukup berpengaruh pada saat penelitian dilakukan diantaranya lingkungan tempat Subjek dirawat saat dilakukan penelitian cukup ramai pada Subjek I dan II ditunjukkan dengan adanya 4 orang perawat yang akan melakukan penelitian dan tindakan pengambilan darah intravena pada Subjek I, sedangkan pada Subjek II hanya 3 orang perawat, serta ada 2 orang keluarga kedua subjek yang saat dilakukan penelitian berada di dalam kamar, pengaruh teman sekamar pada penelitian ini tidak ada, karena pada saat penelitian kedua subjek tidak memiliki teman sekamar.

Umi Solikhah pada tahun 2013 melakukan penelitian terkait efektifitas lingkungan pada anak menunjukkan bahwa lingkungan terapeutik efektif untuk meminimalisasi reaksi hospitalisasi. Pada saat penelitian Subjek II didampingi oleh ibunya, sedangkan pada Subjek I didampingi oleh ayahnya, padahal pada anak-anak cenderung lebih dekat dengan ibu dibandingkan dengan ayah. Hal ini dikarenakan kedekatan ibu akan memberi ketenangan bagi anak. Dengan kehadiran orang yang dicintai akan meminimalkan kesepian dan ketakutan klien. Kehadiran orang tua sangat penting bagi anak-anak yang sedang mengalami nyeri (Hockenberry \& Wilson, 2009).

Menurut Sarfika, Yanti, dan Winda (2015) yang meneliti pengaruh teknik distraksi menonton kartun animasi terhadap skala nyeri anak usia prasekolah. Penelitian tersebut menunjukkan bahwa rata-rata skala nyeri anak yang diberikan teknik distraksi menonton kartun animasi adalah 2,64, menurut rentang skala FLACC skala rata-rata ini berada pada kriteria tidak nyaman. Sedangkan rata-rata skala nyeri anak yang tidak diberikan teknik distraksi menonton kartun animasi adalah 6,36 (nyeri sedang).

Pendapat yang lain dari Agustina, Rohmah, dan Hamid (2015). Penelitian tersebut berjudul pengaruh distraksi 
audiovisual terhadap respons penerimaan injeksi intravena pada anak pra sekolah, hasil penelitiannya menunjukkan bahwa pada kelompok responden yang diberikan distraksi audiovisual selama tindakan injeksi intravena melalui saluran infus dilakukan, yang memberikan respon baik sebesar 86,7 \% dan yang memberikan respons buruk sebesar $13,3 \%$, sedangkan pada kelompok yang diberikan perawatan rutin ruangan atau yang tidak diberikan distraksi audiovisual selama tindakan injeksi intravena melalui saluran infus dilakukan, yang memberikan respons baik sebesar 26,7 \% dan yang memberikan respons buruk sebesar 73,3\%.

\section{Keterbatasan Penelitian}

Keterbatasan Penelitian ini terdiri dari beberapa hal seperti berikut ini

1. Aspek teoritis, pada saat peneliti mencari jurnal-jurnal keperawatan sebagai acuan saat penelitian akan dilaksanakan peneliti mengalami kesulitan karena sedikitnya jumlah jurnal-jurnal keperawatan yang serupa dengan penelitian yang akan dilaksanakan.

2. Aspek metodologis, karena penelitian ini adalah suatu penelitian dengan menggunakan metode penelitian studi kasus yang hanya meneliti dua subjek penelitian saja maka peneliti mengalami keterbatasan pada permasalahan yang kurang kompleks karena datadata yang didapat kurang bervariasi dan beragam.

3. Beberapa hal yang cukup menghambat jalannya penelitian antara lain, saat perawat mengambil darah intravena pada subjek penelitian perawat tersebut terburuburu karena masih ada tugas dan tanggung jawab dari perawat ruangan yang belum terselesaikan maka waktu yang didapat peneliti saat dilakukannya penelitian ini sangatlah terbatas.

4. Kesulitan juga dialami oleh peneliti saat peneliti mencari calon subjek penelitian diruangan peneliti cukup kesulitan karena sedikitnya anak yang dirawat pada usia toddler (1-3 tahun) dan akan dilakukan tindakan pengambilan darah intravena yang sesuai dengan kriteria inklusi dan eksklusi yang sudah ditentukan oleh peneliti di tempat penelitian dilakukan.

5. Dari segi rekaman penelitian, karena kualitas alat rekaman dan yang merekam kurang baik dan berpengalaman menyebabkan rekaman tidak tirlihat secara utuh seperti langsung saat melakukan penelitian, tetapi menimbulkan persepsi-persepsi lain dari video rekaman tersebut.

\section{PENUTUP}

Bedasarkan hasil penelitian yang telah dilakukan maka dapat dapat ditarik kesimpulan saran dan rekomendasi seperti berikut ini.

\section{A. Kesimpulan}

1. Intervensi keperawatan dengan teknik distraksi menonton kartun edukasi pada anak usia toddler terbukti dapat menurunkan skala nyeri pada saat dilakukan tindakan pengambilan darah intravena.

2. Anak yang lebih muda dalam hal ini Subjek I memiliki tingkat nyeri yang 
lebih tinggi dan semakin bertambah dan Subjek II dengan tingkat usia yang lebih tua tingkat nyerinya menjadi lebih rendah.

3. Ditemukan ada beberapa hal yang menyebabkan perbedaan antara skala nyeri dari kedua subjek yang diteliti yaitu antara subjek I dan subjek II yaitu usia anak, lingkungan, pendamping saat penelitian, serta urutan kelahiran dalam keluarga.

\section{B. Saran}

Berdasarkan hasil temuan penelitian diatas maka dapat disampaikan beberapa saran seperti berikut ini :

1. Teknik distraksi menonton kartun edukasi sangat perlu menjadi rujukan dalam melaksanakan asuhan keperawatan khususnya asuhan pada anak pada usia toddler, dilaksanakan secara sungguh-sungguh, karena terbukti teknik ini dapat menurunkan tingkat nyeri saat pengambilan darah intravena pada anak.

2. Sebaiknya calon subjek penelitian lebih dari dua, agar dapat ditemukan permasalahan yang lebih kompleks serta data-data yang didapat lebih bervariasi dan beragam maka dari itu Kepada peneliti yang akan melakukan penelitian dengan tema kasus yang sama dan serupa dengan penelitian ini, sebaiknya subjek penelitian dapat ditambahkan subjek yang akan diteliti yaitu anak usia toddler dan prasekolah. Jadi nantinya hasil penelitian yang didapatkan menjadi lebih bervariasi dan beragam serta peluang untuk mendapatkan calon subjek menjadi lebih banyak dan mudah.
3. Kepada institusi pendidikan, Diharapkan penelitian ini dapat dijadikan referensi untuk penelitian selanjutnya dengan memperluas dari semua materi. Dan memodifikasi lingkungan untuk fasilitas melakukan intervensi teknik distraksi menonton kartun edukasi.

\section{Rekomendasi.}

1. Hasil Penelitian menunjukan bahwa Teknik Distraksi menonton kartun edukasi dapat menurunkan rasa nyeri saat diambil darah intravena maka dari itu teknik ini bisa digunakan untuk melakukan asuhan keperawatan usia toddler dalam rangka menurunkan rasa nyeri pada saat melakukan pengambilan darah intravena pada anak, dengan berkurangnya rasa nyeri ini memudahkan tenaga perawat menjalankan tugasnya.

2. Seyogyanya pengurangan rasa nyeri pada saat pengambilan darah intravena pada anak usia todler dapat meminimalisir kesalahan atau cedera pada anak akibat intervensi yang telah dilakukan untuk itulah teknik ini seharusnya dapat dilakukan oleh para perawat khususnya dalam perawatan anak usia toddler.

3. Untuk menambah referensi tentang teknik distraksi ini maka Perpustakaan kampus dapat disiapkan jurnal-jurnal keperawatan yang beragam, bervariasi, dan terbaru sebagai acuan dilaksanakannya penelitian-penelitian berikutnya. Kalau tidak, setidaknya pada akses pencarian jurnal-jurnal terkait penelitian pada keperawatan melalui internet dapat lebih dipermudah supaya penelitian yang 
dilakukan dapat lebih efektif, efisien, serta akurat.

\section{DAFTAR PUSTAKA}

Agustina, Hirma., Rohmah, Nikmatur., dan Hamid, Muhamad Ali. 2015. Pengaruh Audiovisual Terhadap Respon Penerimaan Injeksi Intravena Pada Anak Pra Sekolah di RSD Kalisat Jember. Jurnal Ilmu Keperawatan.

Alpers, Ann. 2006. Buku Ajar Pediatri Rudolph. Edisi 20. Jakarta: EGC.

Asmadi. 2008. Teknik Prosedural Keperawatan Konsep Dan Aplikasi Kebutuhan

Dasar Klien. Jakarta: Salemba Medika.

Ball, Jane. 2010. Child Health Nursing: Partnering With Children And Families. New Jersey: Pearson.

Barbara A. Brown. 1993. Hematology : Principles And Procedures Lea and Febiger. Philadelphia

Basford Lynn. 2006. Teori dan Praktek Keperawatan., Pendekatan Integral Pada Asuhan Pasien. Alih bahasa: Agung Waluyo et al. Jakarta: EGC

Black, Joyce M. 2014. Keperawatan Medikal Bedah. Edisi 8. Jakarta: Salemba Medika.

Boesoirie, Muhamad Adli., Oktaliansah, Ezra., dan Bisri, Tatang. 2015.

Perbandingan Parasetamol dengan Ketorolak Intravena Sebagai Analgesia Preventif Terhadap Skala Nyeri Pascabedah Labioplasti Pada Pasien Pediatrik. Jurnal Anestesi Perioperatif, Volume 3, Nomor 2: 8186.

Brannon, R., Feist, J., and Updegraff, J.A. 2013. Health Psycology : an introduction to behavior and health, eight edition. USA: Wadsworth.

Carter, B dan Simons, J. 2014. Stories of children's pain lingking evidence to practice. Washington DC: SAGE.
Hidayat, A. Aziz. 2012. Pengantar Kebutuhan Dasar Manusia. Jakarta: Salemba Medika.

Hockenberry, M., \& Wilson, D. 2007. Wongs Nursing Care Of Infants And Children. Canada: Elsevier.

IASP. 2012. IASP Taxonomy. Washington: IASP.

James, J., Ghai, S., and Sharma, N. 2012. Effectiveness of Animated Cartoons as A Distraction Strategy On Behavioral Response To Pain Perception Among Children Undergoing Venipuncture. Nursing and Midwifery Research Journal, Volume 8, Nomor 3: 198-209.

LaRocca, Joanne C. 1998. Terapi Intravena. Edisi 2. Jakarta: EGC.

MacLaren J.E, Cohen L.L. 2005. A Comparison of Distraction Strategies for

Venipuncture Distress in Children. Journal of Pediatric Psycology, Volume 30, Nomor 5: 387-396.

Marandina, Bambang Adi. 2014. Pengkajian Skala Nyeri Di Ruang Perawatan Intensive Liberatur Review. Jurnal Ilmu Keperawatan, Volume 1, Nomor 1.

McCarthy A.M, Kleiber C. 2006. A Conceptual Model of Factors Influencing Children's Resposes To Apainful Procedure When Parents Are Distraction Coaches. Journal of Pediatrics Nursing, Volume 21, Nomor 2: 88-89.

Notoatmodjo, Soekidjo. 2012. Metodologi Penelitian Kesehatan. Jakarta: Rineka Cipta.

Nursalam. 2003. Konsep dan Penerapan Metodologi Penelitian Ilmu Keperawatan: Pedoman Skripsi, Tesis, dan Instrumen Penelitian Keperawatan. Jakarta: Salemba Medika.

Odhner, M. Wegman, D. and Freeland N. 2003. Assessing Pain Control in Nonverbal Critically Patients. Dimentions of Critical Care Nursing, Volume 22, Nomor 6: 260-267. 
Potter, Patricia A. 2005. Buku Ajar Fundamental Keperawatan : konsep, proses, dan praktik. Edisi 4. Jakarta: EGC.

Purwandari, H. 2009. Pengaruh Terapi Seni Dalam Menurunkan Kecemasan Anak Usia Sekolah Yang Menjalani Hospitalisasi. Jakarta: Tesis. Program Pasca Sarjana Fakultas Ilmu Keperawatan Universitas Indonesia

Sarfika, R., Yanti, N., dan Winda, R. 2015. Pengaruh Teknik Distraksi Menonton Kartub Animasi Terhadap Skala Nyeri Anak Usia Prasekolah Saat Pemasangan Infus Di Instalasi Rawat Inap Anak RSUP DR. M. Djamil Padang. Ners Jurnal Keperawatan, Volume 11, Nomor 1: 32-40.

Sastroasmoro, Sudigdo. 2014. Dasar dasar Metodologi Penelitian Klinis. Edisi 5. Jakarta: Sagung Seto.

Sefrina, A., Nurhaeni, N., dan Hayati, H. 2016. Aplikasi Theory of Unpleasant Symptoms (TOUS) Pada Anak Yang Mengalami Nyeri Di Ruang Rawat Non Infeksi RSCM Jakarta. Jurnal Keperawatan Muhammadiyah, Volume 1, Nomor 1: 32-39.

Shayevitz, J. R. \& Malviya, S. 1997. The FLACC : A Behavioral Scale For Scoring Postoperative Pain In Young Children. Pediatric Nursing, Volume 23, Nomor 3: 293-297.

Solikhah, Umi. 2013. Efektifitas Lingkungan Terapetik Terhadap Reaksi Hospitalisasi Pada Anak. Jurnal Keperawatan Anak, Volume 1, Nomor 1: 1-9.

Sriwahyuningsih, I. 2016. Studi Literatur : Instrumen Pengkajian Nyeri Pada Pasien Kritis Dewasa Yang Terpasang Ventilator. Jurnal Keperawatan dan Pemikiran Ilmiah. Volume 2, Nomor 2: 1-7.

Sugiyono. 2012. Metode Penelitian Kuantitatif, Kualitatif, dan Kombinasi (Mixed Methods). Bandung: Alfabeta.
Sulistiyani, E. 2009. Pengaruh Kompres Es Batu Pada Anak Usia Prasekolah Yang Dilakukan Pemasangan Infus Di RSUPN Dr. Cipto Mangunkusumo. Jakarta: Tesis. Program Pasca Sarjana Fakultas Ilmu Keperawatan Universitas Indonesia.

Supartini, Yupi. 2004. Buku Ajar Konsep Dasar Keperawatan Anak. Jakarta: EGC.

Suwigdjo, Purwo. 2008. Ketepatan Posisi Naso Gastrik Tube (NGT) Menggunakan Metode Aspirasi, Metode Auskultasi Dan Metode Merendam Ujung Selang NGT Ke Dalam Air Dengan Konfirmasi Rontgen Di UGD Rumah Sakit Dr. Hasan Sadikin Bandung. Jurnal Ilmu Keperawatan

Syamsiah, Nita \& Muslihat, Endang. 2015.

Pengaruh Terapi Relaksasi Autogenik Terhadap Tingkat Nyeri Akut Pada Pasien Abdominal Pain Di IGD RSUD Karawang. Jurnal Ilmu Keperawatan, Volume III, Nomor 1: $2338-7246$.

Tamsuri. 2007. Konsep Dan Penatalaksanaan Nyeri. Jakarta: EGC.

Utami, Yuli. 2014. Dampak Hospitalisasi Terhadap Perkembangan Anak. Jurnal Ilmiah WIDYA, Volume 2, Nomor 2: 2337-6686.

Wong, Donna L. 2008. Buku Ajar Keperawatan Pediatrik Wong. Edisi 6. Jakarta: EGC.

Yudiyanta,., Khoirunnisa, N., dan Novitasari, R. W. 2015. Assessment Nyeri. CDK-226, Volume 42, Nomor 3: 214-234.

Zemsky, W.T. 2008. Optimizing the Management of Peripheral Venous Access Pain in Children: Evidence, Impact, and Implementation. Official journal of the American Academy of Pediatrics, 122. 